Article

\title{
The Impact of the Composition Effect on Ferromagnetic Properties of $\mathrm{Tb}_{2} \mathrm{Co}_{2} \mathrm{Ga}$
}

\author{
Seiya Tanaka ${ }^{1}$, Hirotaka Terada $^{1}$, Naoki Shirakawa ${ }^{2}{ }^{(\mathbb{C}}$, Masami Tsubota $^{3}(\mathbb{1})$ and \\ Jiro Kitagawa ${ }^{1, *(D)}$ \\ 1 Department of Electrical Engineering, Faculty of Engineering, Fukuoka Institute of Technology, \\ 3-30-1 Wajiro-higashi, Higashi-ku, Fukuoka 811-0295, Japan; s1552026@bene.fit.ac.jp (S.T.); \\ s1452006@bene.fit.ac.jp (H.T.) \\ 2 Flexible Electronics Research Center, National Institute of Advanced Industrial Science and Technology, \\ Tsukuba, Ibaraki 305-8565, Japan; shirakawa.n@aist.go.jp \\ 3 Physonit Inc., 6-10 Minami-Horikawa, Kaita Aki, Hiroshima 736-0044, Japan; tsubota@physonit.jp \\ * Correspondence: j-kitagawa@fit.ac.jp
}

Received: 18 October 2019; Accepted: 19 November 2019; Published: 20 November 2019

check for updates

\begin{abstract}
The ferromagnetic properties of $\mathrm{Tb}_{2} \mathrm{Co}_{2} \mathrm{Ga}$, crystallizing into an orthorhombic $\mathrm{W}_{2} \mathrm{CoB}_{2}$-type structure, were investigated by preparing 11 polycrystalline samples with different starting atomic compositions. We found that $\mathrm{Tb}_{2} \mathrm{Co}_{2} \mathrm{Ga}$ possesses a homogeneity range in the ternary phase diagram. The Curie temperature $T_{C}$ is sensitive to the atomic composition and ranges rather widely, i.e., from 75 to $145 \mathrm{~K}$. For the samples with a $T_{\mathrm{C}}$ above $90 \mathrm{~K}$, the nearest $\mathrm{Tb}-\mathrm{Tb}$ and the $\mathrm{Tb}-\mathrm{Co}$ distances would be important factors deciding $T_{C}$, considering the RKKY interaction through the hybridization between $\mathrm{Tb}$ and $\mathrm{Co}$ atoms. An anisotropic change of two kinds of $\mathrm{Co}-\mathrm{Tb}-\mathrm{Co}$ angles in the octahedron formed by two $\mathrm{Tb}$ and four $\mathrm{Co}$ atoms occurs in the samples with a $T_{\mathrm{C}}$ lower than $90 \mathrm{~K}$. Such a change of octahedral parameters seems to be related to a difference of shapes in the ac magnetization anomaly at $T_{C}$ between the samples in the lowest $T_{C}(\sim 75 \mathrm{~K})$ group and those in the other groups.
\end{abstract}

Keywords: ferromagnetism; $\mathrm{W}_{2} \mathrm{CoB}_{2}$-type structure; composition effect; magnetic measurements; lattice parameters

\section{Introduction}

Several ferromagnetic compounds of $\mathrm{R}_{2} \mathrm{Co}_{2} \mathrm{Al}$ and $\mathrm{R}_{2} \mathrm{Co}_{2} \mathrm{Ga}(\mathrm{R}=$ heavy rare earth) with an orthorhombic $\mathrm{W}_{2} \mathrm{CoB}_{2}\left(\mathrm{Mo}_{2} \mathrm{NiB}_{2}\right)$-type structure [1] are attractive as magnetic refrigeration materials [2-5]. Recently, we studied the orthorhombic $W_{3} \mathrm{CoB}_{3}$-type $\mathrm{Tb}_{3} \mathrm{Co}_{3} \mathrm{Ga}$ that is located near $\mathrm{Tb}_{2} \mathrm{Co}_{2} \mathrm{Ga}_{\text {in }}$ the ternary phase diagram [6]. A polycrystalline $\mathrm{Tb}_{3} \mathrm{Co}_{3} \mathrm{Ga}$ sample also showed ferromagnetism, but the Curie temperature $T_{C}$ ranged from $90 \mathrm{~K}$ to $117 \mathrm{~K}$, depending on the starting atomic composition. The actual atomic composition that correlates with the starting composition has revealed the existence of a homogeneity range, especially along the Ga concentration. The crystal structure parameters, which slightly change with the atomic composition, severely affect $T_{\mathrm{C}}$.

It has been recently reported [7] that $\mathrm{Tb}_{2} \mathrm{Co}_{2} \mathrm{Ga}$ is a ferromagnet with $T_{\mathrm{C}}=86 \mathrm{~K}$. Figure $1 \mathrm{a}, \mathrm{b}$ shows the crystal structure of $\mathrm{Tb}_{2} \mathrm{Co}_{2} \mathrm{Ga}$. In the orthorhombic structure, with the space group of Immm (No.71), Tb, Co, and Ga atoms occupy the crystallographic 4h, 4f, and $2 \mathrm{a}$ sites, respectively. Two Tb and the nearest neighboring four Co atoms build an octahedron, the arrangement of which can be regarded as a rectangular lattice in the $a-b$ plane (see Figure $1 b$ ). The rectangular lattice stacks along the $c$-axis. The isostructural $\mathrm{Tb}_{2} \mathrm{Co}_{2} \mathrm{Al}$ has been reported to be a ferromagnet [4] below $111 \mathrm{~K}$. A neutron diffraction study [4] has clarified that $\mathrm{Tb}$ and $\mathrm{Co}$ sublattices form a $c$-axis ferrimagnetic ordering. The magnetic moment of $\mathrm{Tb}$ at $2 \mathrm{~K}$ is $8.86 \mu_{\mathrm{B}}$, which dominates over that of Co with $0.26 \mu_{\mathrm{B}}$. 
(a)

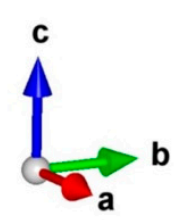

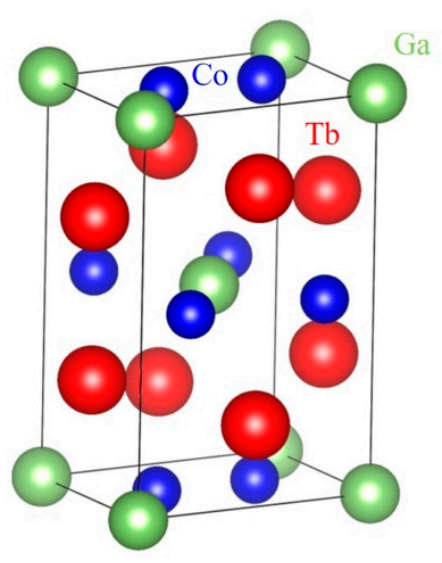

(b)

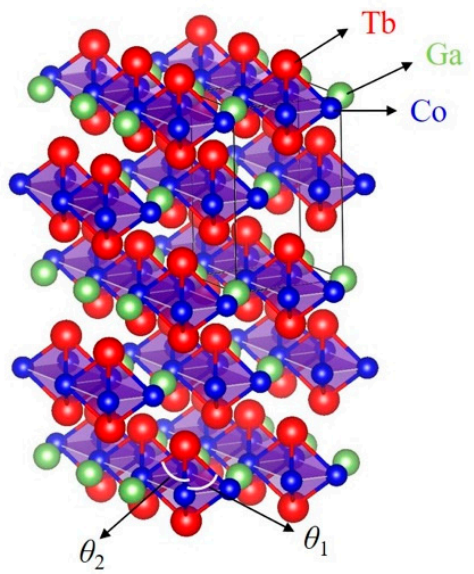

Figure 1. (a) Unit cell of $\mathrm{Tb}_{2} \mathrm{Co}_{2} \mathrm{Ga}$. (b) Crystal structure of $\mathrm{Tb}_{2} \mathrm{Co}_{2} \mathrm{Ga}$, emphasizing the polyhedral arrangement. The solid line represents the unit cell. $\theta_{1}$ and $\theta_{2}$ are $\mathrm{Co}-\mathrm{Tb}-\mathrm{Co}$ angles in the octahedron formed by two $\mathrm{Tb}$ atoms and the nearest neighboring four Co atoms.

As in the case of $\mathrm{Tb}_{3} \mathrm{Co}_{3} \mathrm{Ga}$, we can expect a composition effect for $\mathrm{Tb}_{2} \mathrm{Co}_{2} \mathrm{Ga}$. If a homogeneity range exists in a metallurgical phase diagram, the magnetic ordering temperature often varies depending on the atomic composition. Such a composition effect is actually observed [8] in $\mathrm{Nd}_{3} \mathrm{Pd}_{20} \mathrm{Ge}_{6}$, which shows a slight decrease of the Néel temperature as the Pd atomic composition is increased from 19.2 to 21. Another example is $\mathrm{Mn}_{1+\mathrm{x}} \mathrm{Ga}$, which is a ferromagnet showing a reduced $T_{\mathrm{C}}$ with decreasing Mn concentration [9]. The study that found this effect presented a detailed composition effect of ferromagnetic properties that depend on the crystal structure parameters.

If $\mathrm{Tb}_{2} \mathrm{Co}_{2} \mathrm{Ga}$ shows a composition effect based on ferromagnetic properties, the effect would depend on the crystal structure parameters, which may play a crucial role in the design of magnetic refrigeration materials with a $\mathrm{W}_{2} \mathrm{CoB}_{2}$-type structure. Therefore, it is important to know the relationships between the crystal structure parameters and ferromagnetic properties in $\mathrm{W}_{2} \mathrm{CoB}_{2}$-type compounds; however, this has not been well explored. In this paper, we report the composition effect of the magnetic properties of polycrystalline $\mathrm{Tb}_{2} \mathrm{Co}_{2} \mathrm{Ga}$ by a metallographic examination and measurement of the magnetic susceptibility and the magnetization curve.

\section{Materials and Methods}

Eleven polycrystalline samples, A to K, with different starting atomic compositions, as listed in Table 1, were synthesized by a home-made arc furnace. The constituent elements of $\mathrm{Tb}$ (Nippon Yttrium, Omuta, Japan, bulk, 99.9\%), Co (Kojundo Chemical Laboratory, Sakado, Japan, bulk, 99.9\%) and Ga (Kojundo Chemical Laboratory, Sakado, Japan, bulk, 99.99\%), placed on a water-cooled $\mathrm{Cu}$ hearth, were arc-melted in an Ar atmosphere. Each as-cast sample was sealed in an evacuated quartz tube, which was heated to $650^{\circ} \mathrm{C}$ and held at that temperature for 4 days. In Table 1 , all the samples are labeled into four groups (G1, G2, G3, and G4) based on the value of $T_{C}$, and the samples in the G4 group are further divided into three subgroups (SG4-1, SG4-2 and SG4-3), as explained below. The starting atomic composition covers Tb: $39-45 \%$, Co: $36-42 \%$ and Ga: $17-24 \%$. The location of each sample, with its starting atomic composition, is depicted in the Tb-Co-Ga ternary phase diagram (see Figure 2a), in which the impurity phases detected in this study are also marked. 
Table 1. Starting atomic compositions and determined compositions of the main phase by EDX measurement for prepared samples.

\begin{tabular}{ccccc}
\hline Group & Subgroup & Sample & $\begin{array}{c}\text { Starting } \\
\text { Composition }\end{array}$ & $\mathrm{Tb}_{2} \mathrm{Co}_{2} \mathrm{Ga}$ Main Phase \\
\hline $\mathrm{G} 1$ & - & $\mathrm{A}$ & $\mathrm{Tb}_{41.7} \mathrm{Co}_{41.7} \mathrm{Ga}_{16.6}$ & $\mathrm{~Tb}_{40.1(6)} \mathrm{Co}_{39.8(8)} \mathrm{Ga}_{20.1(4)}$ \\
$\mathrm{G} 1$ & - & $\mathrm{B}$ & $\mathrm{Tb}_{45.0} \mathrm{Co}_{38.0} \mathrm{Ga}_{17.0}$ & $\mathrm{~Tb}_{39.9(8)} \mathrm{Co}_{40.7(4)} \mathrm{Ga}_{19.4(9)}$ \\
$\mathrm{G} 2$ & - & $\mathrm{C}$ & $\mathrm{Tb}_{41.4} \mathrm{Co}_{39.4} \mathrm{Ga}_{19.2}$ & $\mathrm{~Tb}_{39.9(3)} \mathrm{Co}_{39.4(2)} \mathrm{Ga}_{20.6(5)}$ \\
$\mathrm{G} 2$ & - & $\mathrm{D}$ & $\mathrm{Tb}_{43.9} \mathrm{Co}_{36.8} \mathrm{Ga}_{19.3}$ & $\mathrm{~Tb}_{40.3(8)} \mathrm{Co}_{38.8(9)} \mathrm{Ga}_{21.0(2)}$ \\
$\mathrm{G} 3$ & - & $\mathrm{E}$ & $\mathrm{Tb}_{42.0} \mathrm{Co}_{38.0} \mathrm{Ga}_{20.0}$ & $\mathrm{~Tb}_{39.7(8)} \mathrm{Co}_{38.6(7)} \mathrm{Ga}_{21.7(5)}$ \\
$\mathrm{G} 3$ & - & $\mathrm{F}$ & $\mathrm{Tb}_{42.9} \mathrm{Co}_{35.7} \mathrm{Ga}_{21.4}$ & $\mathrm{~Tb}_{39.8(6)} \mathrm{Co}_{39.7(5)} \mathrm{Ga}_{21.5(4)}$ \\
$\mathrm{G} 4$ & $\mathrm{SG} 4-1$ & $\mathrm{G}$ & $\mathrm{Tb}_{41.0} \mathrm{Co}_{37.0} \mathrm{Ga}_{22.0}$ & $\mathrm{~Tb}_{39.6(7)} \mathrm{Co}_{37.7(9)} \mathrm{Ga}_{22.7(6)}$ \\
$\mathrm{G} 4$ & $\mathrm{SG} 4-1$ & $\mathrm{H}$ & $\mathrm{Tb}_{40.6} \mathrm{Co}_{38.7} \mathrm{Ga}_{20.7}$ & $\mathrm{~Tb}_{39.5(4)} \mathrm{Co}_{38.5(9)} \mathrm{Ga}_{22.1(8)}$ \\
$\mathrm{G} 4$ & $\mathrm{SG} 4-2$ & $\mathrm{I}$ & $\mathrm{Tb}_{40.0} \mathrm{Co}_{40.0} \mathrm{Ga}_{20.0}$ & $\mathrm{~Tb}_{39.4(5)} \mathrm{Co}_{37.7(6)} \mathrm{Ga}_{22.9(9)}$ \\
$\mathrm{G} 4$ & $\mathrm{SG} 4-3$ & $\mathrm{~J}$ & $\mathrm{~Tb}_{38.9} \mathrm{Co}_{37.0} \mathrm{Ga}_{24.1}$ & $\mathrm{~Tb}_{39.1(1)} \mathrm{Co}_{38.4(6)} \mathrm{Ga}_{22.5(8) \prime}$ \\
$\mathrm{G} 4$ & $\mathrm{SG} 4-3$ & $\mathrm{~K}$ & $\mathrm{~Tb}_{39.0} \mathrm{Co}_{39.0} \mathrm{Ga}_{22.0}$ & $\mathrm{~Tb}_{39.1(3)} \mathrm{Co}_{38.0(4)} \mathrm{Ga}_{22.9(2)}$ \\
\hline
\end{tabular}
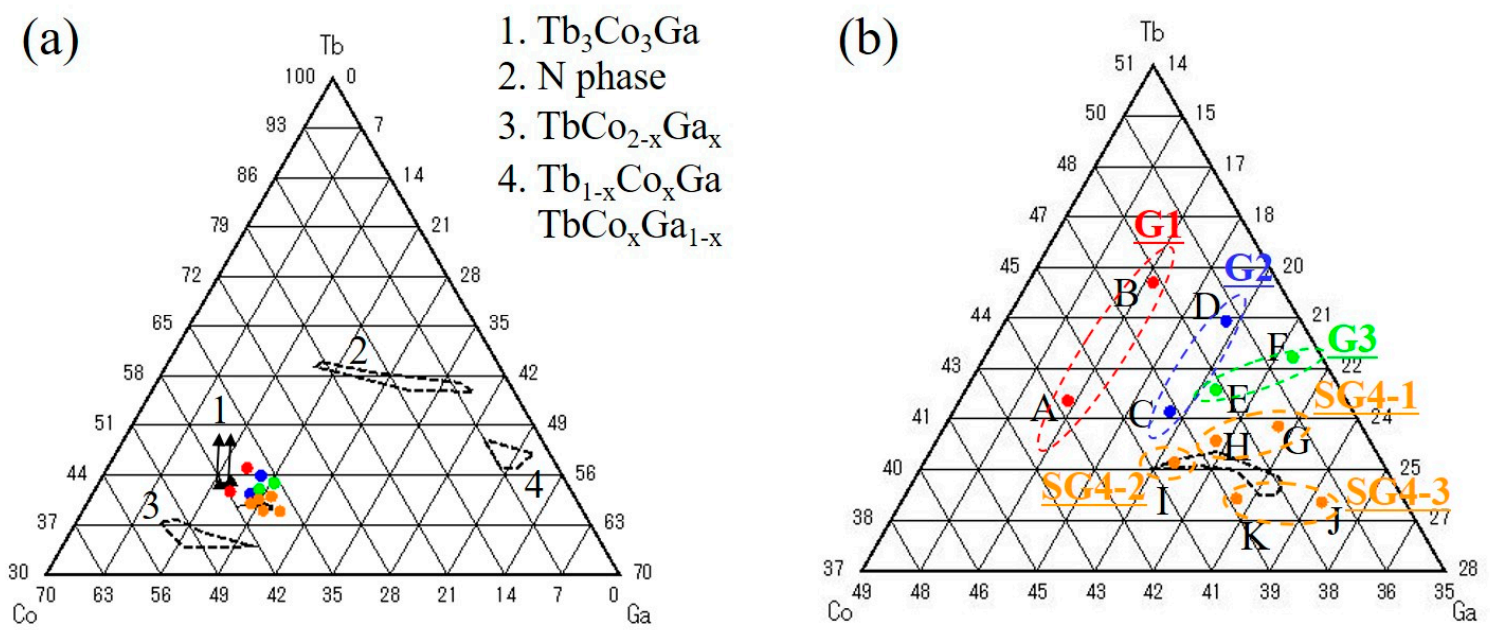

Figure 2. (a) Ternary phase diagram of the $\mathrm{Tb}-\mathrm{Co}-\mathrm{Ga}$ system for prepared samples plotted based on their starting compositions (filled colored circles). The impurity phases $\left(\mathrm{Tb}_{3} \mathrm{Co}_{3} \mathrm{Ga}\right.$, the $\mathrm{N}$ phase, $\mathrm{TbCo}_{2-\mathrm{x}} \mathrm{Ga}_{\mathrm{x}}, \mathrm{Tb}_{1-\mathrm{x}} \mathrm{Co}_{\mathrm{x}} \mathrm{Ga}$ and $\left.\mathrm{TbCo}_{\mathrm{x}} \mathrm{Ga}_{1-\mathrm{x}}\right)$ are also added. The area surrounded by broken lines indicates a range of the solid solution detected by EDX measurement. The homogeneity range of $\mathrm{Tb}_{3} \mathrm{Co}_{3} \mathrm{Ga}$ is depicted by the black triangles. (b) Expanded diagram around the $\mathrm{Tb}_{2} \mathrm{Co}_{2} \mathrm{Ga}$ phase. The area surrounded by black broken-lines indicates a range of the solid solution of $\mathrm{Tb}_{2} \mathrm{Co}_{2} \mathrm{Ga}$ detected by EDX measurement.

X-ray diffraction patterns were recorded by using a powder X-ray diffractometer (XRD-7000L Shimadzu, Kyoto, Japan,) with $\mathrm{Cu}-\mathrm{K} \alpha$ radiation. The $2 \theta$ range was between $10^{\circ}$ and $90^{\circ}$. The microstructure of the prepared sample was checked by a field emission scanning electron microscope (JSM-7100F FE-SEM; JEOL, Akishima, Japan,), and the atomic composition in each area of the sample was determined by an energy dispersive $X$-ray (EDX) spectrometer attached to the FE-SEM.

The temperature dependence of ac magnetic susceptibility $\chi_{\mathrm{ac}}(\mathrm{T})$ between $3 \mathrm{~K}$ and $300 \mathrm{~K}$ was measured by a home-made system in a closed-cycle He gas cryostat. The amplitude and frequency of the ac field were $5 \mathrm{Oe}$ and $800 \mathrm{~Hz}$, respectively. The temperature dependence of dc magnetic susceptibility $\chi_{\mathrm{dc}}(\mathrm{T})$ between $5 \mathrm{~K}$ and $300 \mathrm{~K}$, and the magnetization curves were measured by a MPMS magnetometer (Quantum Design, San Diego, CA, USA). 


\section{Results and Discussion}

\subsection{XRD Pattern and Microstructure}

The X-ray diffraction (XRD) patterns of all samples are shown in Figure 3, which also includes the simulated pattern of $\mathrm{Tb}_{2} \mathrm{Co}_{2} \mathrm{Ga}$. Each pattern of the main phase matches with that of $\mathrm{Tb}_{2} \mathrm{Co}_{2} \mathrm{Ga}$, while obvious impurity peaks appear in the samples $\mathrm{H}$ to $\mathrm{K}$. The impurity phases are discussed in the results of EDX measurement. From samples A to K, each peak position shifts, indicating a change of lattice parameters and the existence of a homogeneity range. The composition dependences of the crystal structure parameters are explained after showing the results of metallographic examinations.

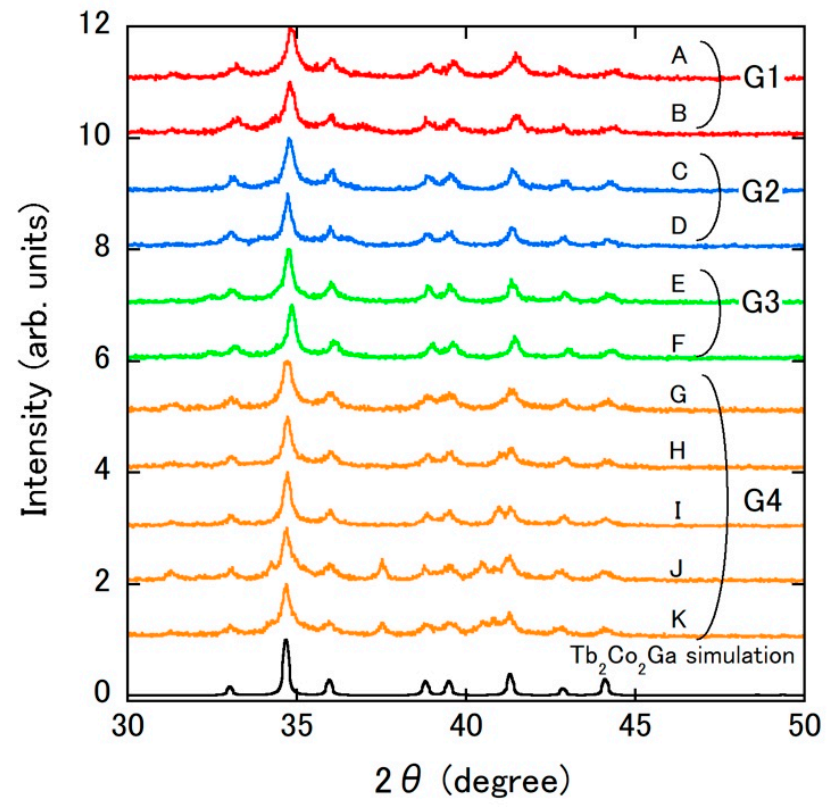

Figure 3. XRD patterns of prepared samples. The simulated pattern of $\mathrm{Tb}_{2} \mathrm{Co}_{2} \mathrm{Ga}$ with $a=4.103 \AA$, $b=$ $5.421 \AA$ and $c=8.433 \AA$ is also shown. The origin of each pattern is shifted by an integer value.

Back-scattered electron images obtained by FE-SEM with electron beams of $15 \mathrm{keV}$ are shown in Figure $4 \mathrm{a}-\mathrm{f}$ for the samples $\mathrm{A}$ to $\mathrm{F}$, and in Figure 5a-e for samples $\mathrm{G}$ to $\mathrm{K}$, respectively. The atomic compositions obtained by EDX measurement of all the samples are listed in Tables 1 and 2 . The number of data collection points per sample is 10 . The composition of the main phase for each sample is close to $\mathrm{Tb}_{2} \mathrm{Co}_{2} \mathrm{Ga}$. In the samples $\mathrm{A}$ to $\mathrm{C}$, the compositions of the $\mathrm{Tb}_{2} \mathrm{Co}_{2} \mathrm{Ga}$ phases are almost stoichiometric. Going on to samples $\mathrm{C}$ to $\mathrm{K}$, a gradual replacement of $\mathrm{Tb}$ and $\mathrm{Co}$ atoms by $\mathrm{Ga}$ atom is observed (see Table 1). Thus, $\mathrm{Tb}_{2} \mathrm{Co}_{2} \mathrm{Ga}$ possesses a homogeneity range as indicated by black broken lines in Figure $2 \mathrm{~b}$. In this study, the homogeneity range is defined as the composition range detected by EDX for a target compound. The samples A and B contain a small amount of $\mathrm{Tb}_{3} \mathrm{Co}_{3} \mathrm{Ga}_{\text {phase, }}$ located near these samples in the ternary phase diagram (see Figure 2a). When the Ga concentration of the $\mathrm{Tb}_{2} \mathrm{Co}_{2} \mathrm{Ga}$ phase is below $21.7 \%$, it is accompanied by the $\mathrm{N}$ phase (see Tables 1 and 2 ), the amount of which is rather large in samples $B$ and D (see Figure $4 b, d$ ). This is consistent with the phase relation displayed in Figure $2 b$. The pseudo binary $\mathrm{TbCo}_{2-\mathrm{x}} \mathrm{Ga}_{\mathrm{x}}$ appears in samples A, C, G, H, I, and K, which are located near $\mathrm{TbCo}_{2-\mathrm{x}} \mathrm{Ga}_{\mathrm{x}}$ (see Figure 2a). Because the locations of samples $\mathrm{G}$ to $\mathrm{K}$ are rather far away from that of the $\mathrm{N}$ phase, these samples do not contain the $\mathrm{N}$ phase; however, another impurity phase is detected, shown as small bright areas in Figure 5a-e. The impurity phase is presumably $\mathrm{Tb}_{1-x} \mathrm{Co}_{x} \mathrm{Ga}$ for the samples $\mathrm{G}, \mathrm{H}$, I, and $\mathrm{K}$, or $\mathrm{TbCo}_{\mathrm{x}} \mathrm{Ga}_{1-\mathrm{x}}$ for sample J. In sample J, the $\mathrm{Tb}_{2} \mathrm{Co}_{2} \mathrm{Ga}$ phase seems to be inhomogeneous, which is deduced by the observation of two phases with slightly different atomic compositions, and the $\chi_{\mathrm{ac}}(\mathrm{T})$ results, as mentioned below. 
(a) A (G1)

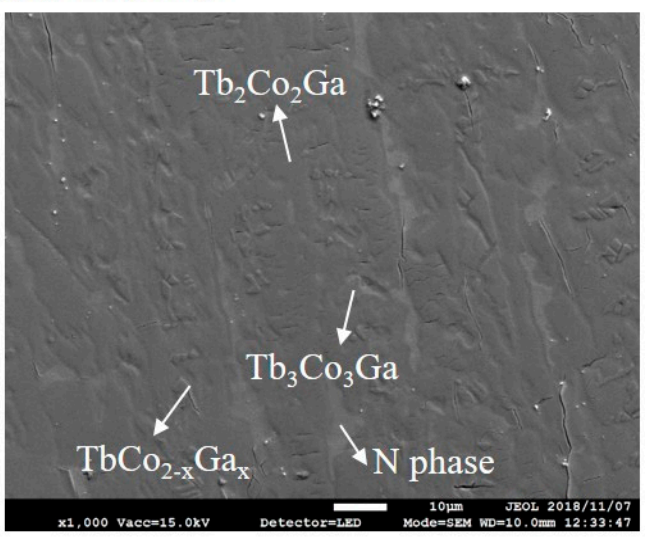

(c) $\mathrm{C}(\mathrm{G} 2)$

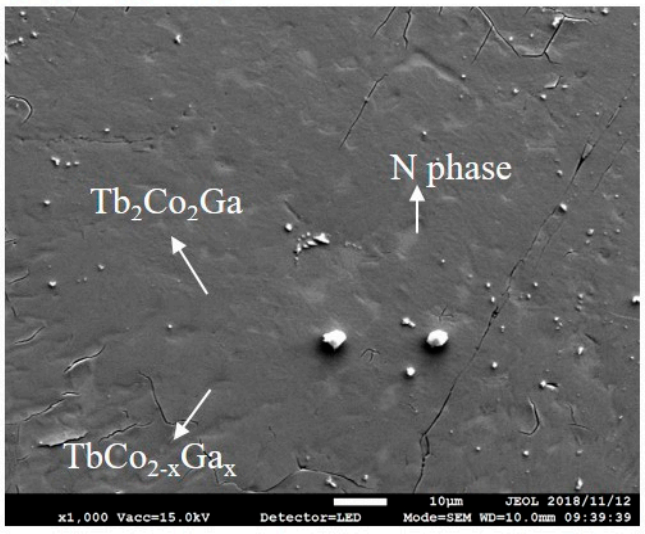

(e) E (G3)

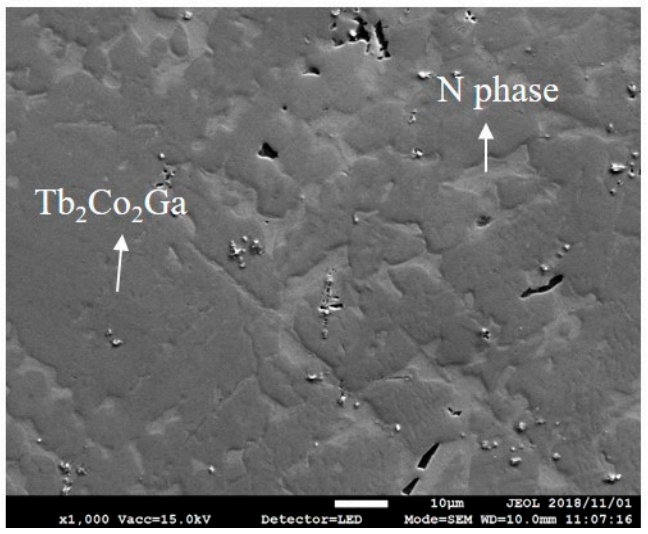

(b) B (G1)

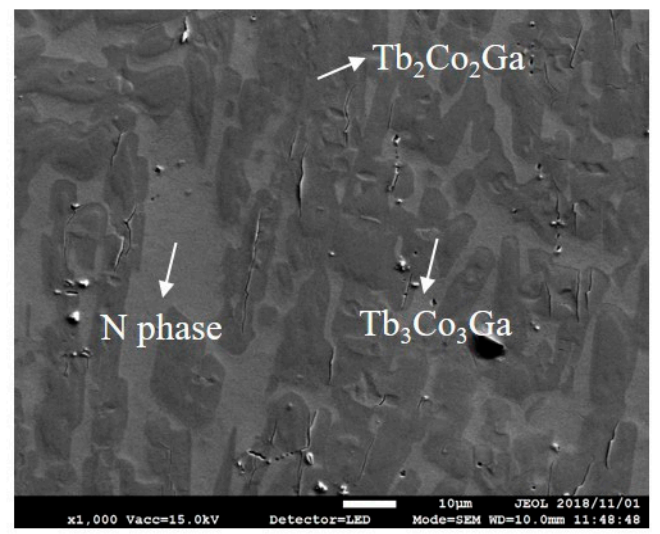

(d) D (G2)

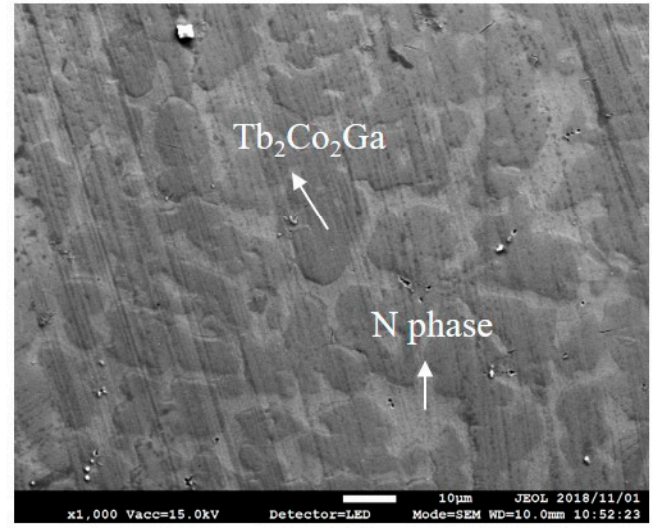

(f) F (G3)

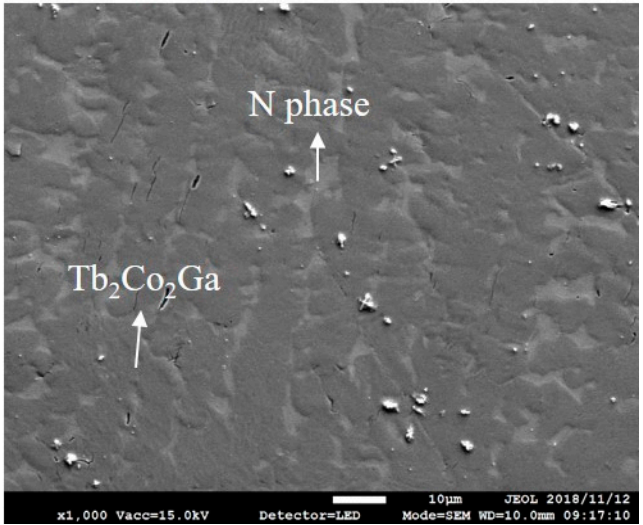

Figure 4. Back-scattered electron (15 keV) images of samples (a) A, (b) B, (c) C, (d) D, (e) E, and (f) F, respectively.

The lattice parameters of all samples were obtained by the least square method with the help of RIETAN-FP program $[10,11]$ using the XRD patterns listed in Table 3 . The actual fitting range of $2 \theta$ was between $10^{\circ}$ and $90^{\circ}$, in which impurity phases with known crystal structures are also considered, but diffraction peaks originating from impurity phases with unknown structures are eliminated. Focusing on the Ga-concentration dependence of the obtained lattice parameters, it can be said that $a$ increases with the increase of Ga concentration (see also Figure 9a). On the other hand, $b$ (c) monotonously increases (decreases) from sample A to F (in the G1, G2 and G3 groups); the sample dependence is 
not so straightforward in the G4 group. Samples G to I show the slight contraction of $b$ compared to sample F, but the opposite behavior is observed in samples J and K. Compared to $c$ of sample F, $c^{\prime}$ s of samples $\mathrm{G}$ and $\mathrm{H}$ are decreased, although samples I, J, and K show an increase of $c$.

\section{(a) $\mathrm{G}(\mathrm{G} 4)$}

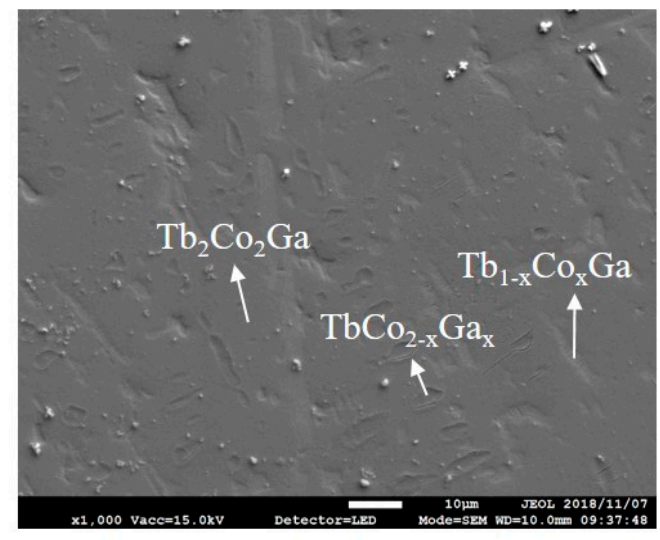

(c) I (G4)

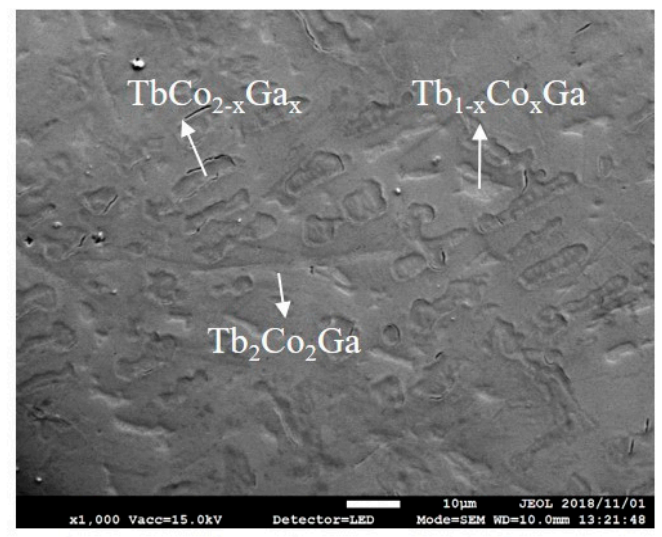

(b) H (G4)

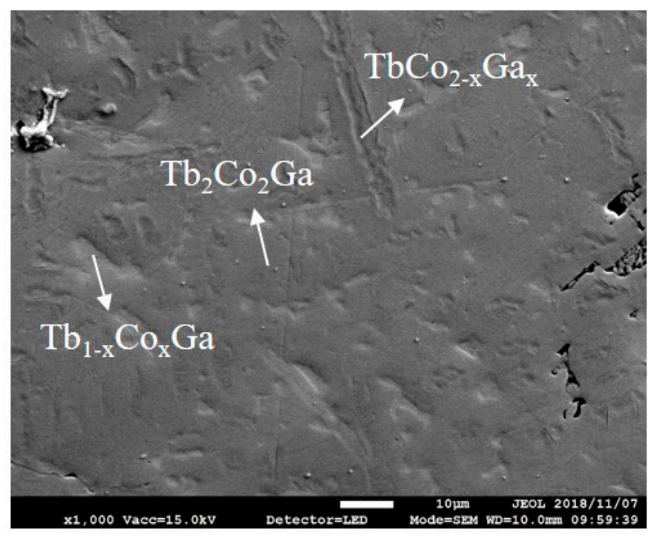

(d) J (G4)

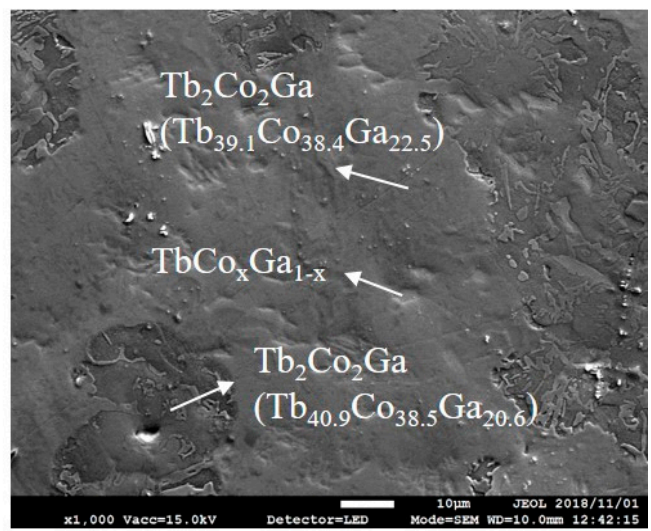

\section{(e) K (G4)}

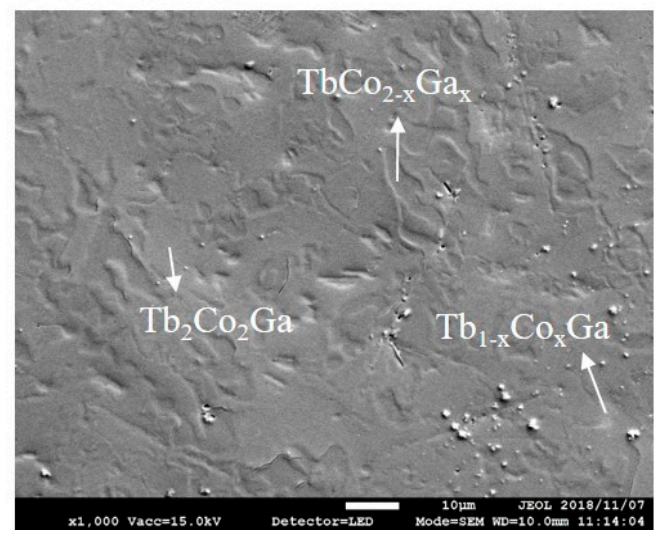

Figure 5. Back-scattered electron (15 keV) images of samples (a) $\mathrm{G},(\mathbf{b}) \mathrm{H},(\mathbf{c}) \mathrm{I},(\mathbf{d}) \mathrm{J}$, and (e) K, respectively. 
Table 2. Atomic compositions of impurity phases determined by EDX measurement for prepared samples.

\begin{tabular}{|c|c|c|c|c|c|c|}
\hline Group & Subgroup & Sample & $\mathrm{Tb}_{3} \mathrm{Co}_{3} \mathrm{Ga}$ & $\mathbf{N}$ phase & $\mathrm{TbCo}_{2-\mathrm{x}} \mathrm{Ga}_{\mathrm{x}}$ & $\begin{array}{c}\mathrm{Tb}_{1-\mathrm{x}} \mathrm{Co}_{\mathrm{x}} \mathrm{Ga}(\mathrm{G}, \mathrm{H}, \mathrm{I}, \mathrm{K}) \\
\quad \text { or } \mathrm{TbCo}_{\mathrm{x}} \mathrm{Ga}_{1-\mathrm{x}}(\mathrm{J})\end{array}$ \\
\hline G1 & - & $\mathrm{A}$ & $\mathrm{Tb}_{42.6(4)} \mathrm{Co}_{42.5(1)} \mathrm{Ga}_{14.9(3)}$ & $\mathrm{Tb}_{59.2(6)} \mathrm{Co}_{22.5(7)} \mathrm{Ga}_{18.3(3)}$ & $\mathrm{Tb}_{37.3(8)} \mathrm{Co}_{52.4(9)} \mathrm{Ga}_{10.3(9)}$ & - \\
\hline G1 & - & B & $\mathrm{Tb}_{43.1(2)} \mathrm{Co}_{40.9(5)} \mathrm{Ga}_{16.0(7)}$ & $\mathrm{Tb}_{59.9(6)} \mathrm{Co}_{21.4(8)} \mathrm{Ga}_{18.8(6)}$ & - & - \\
\hline G2 & - & $\mathrm{C}$ & $\begin{array}{ll}-101(2) & -\end{array}$ & $\mathrm{Tb}_{56(1)} \mathrm{Co}_{13(1)} \mathrm{Ga}_{31(1)}$ & $\mathrm{Tb}_{38(1)} \mathrm{Co}_{50(1)} \mathrm{Ga}_{12(1)}$ & - \\
\hline G2 & - & $\mathrm{D}$ & - & $\mathrm{Tb}_{58.4(8)} \mathrm{Co}_{15.8(8)} \mathrm{Ga}_{25.8(3)}$ & $\begin{array}{lll}50(1)-1 & -\end{array}$ & - \\
\hline G3 & - & $\mathrm{E}$ & - & $\mathrm{Tb}_{57(1)} \mathrm{Co}_{6(2)} \mathrm{Ga}_{36.8(8)}$ & - & - \\
\hline G3 & - & $\mathrm{F}$ & - & $\mathrm{Tb}_{55.7(8)} \mathrm{Co}_{5(1)} \mathrm{Ga}_{39.3(9)}$ & - & - \\
\hline G4 & SG4-1 & G & - & $\begin{array}{c}- \\
-1)(0)\end{array}$ & $\mathrm{Tb}_{33.8(8)} \mathrm{Co}_{50.8(9)} \mathrm{Ga}_{15.4(3)}$ & $\mathrm{Tb}_{45.6(3)} \mathrm{Co}_{4.2(8)} \mathrm{Ga}_{50.3(3)}$ \\
\hline G4 & SG4-1 & $\mathrm{H}$ & - & - & $\mathrm{Tb}_{36(1)} \mathrm{Co}_{48(1)} \mathrm{Ga}_{16(1)}$ & $\mathrm{Tb}_{45(1)} \mathrm{Co}_{5(1)} \mathrm{Ga}_{49(1)}$ \\
\hline G4 & SG4-2 & I & - & - & $\mathrm{Tb}_{34.0(5)} \mathrm{Co}_{51.4(8)} \mathrm{Ga}_{14.5(5)}$ & $\mathrm{Tb}_{44.9(3)} \mathrm{Co}_{7(2)} \mathrm{Ga}_{48(2)}$ \\
\hline G4 & SG4-3 & $\mathrm{J}$ & - & - & 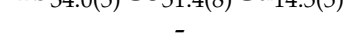 & $\mathrm{Tb}_{49(1)} \mathrm{Co}_{7(2)} \mathrm{Ga}_{43(1)}$ \\
\hline G4 & SG4-3 & $\mathrm{K}$ & - & - & $\mathrm{Tb}_{34.0(5)} \mathrm{Co}_{42.8(9)} \mathrm{Ga}_{23.2(5)}$ & $\mathrm{Tb}_{47(1)} \mathrm{Co}_{2.0(9)} \mathrm{Ga}_{50(1)}$ \\
\hline
\end{tabular}


Table 3. Atomic composition, lattice parameters, cell volume $V, T_{\mathrm{C}}$ determined by $\chi_{\mathrm{ac}}, \mu_{\mathrm{eff}}$ and $\Theta$ of each $\mathrm{Tb}_{2} \mathrm{Co}_{2} \mathrm{Ga} \mathrm{sample}$

\begin{tabular}{|c|c|c|c|c|c|c|c|c|c|c|}
\hline Group & Subgroup & Sample & $\begin{array}{l}\text { Composition of } \\
\mathrm{Tb}_{2} \mathrm{Co}_{2} \mathrm{Ga}\end{array}$ & $a(\AA ̊)$ & $b(\AA ̊)$ & $c(\AA ̊)$ & $V\left(\AA^{3}\right)$ & $T_{\mathrm{C}}(\mathrm{K})$ & $\begin{array}{c}\mu_{\text {eff }} \\
\left(\mu_{\mathrm{B}} / \mathrm{Tb}\right)\end{array}$ & $\Theta(\mathrm{K})$ \\
\hline G1 & - & A & $\mathrm{Tb}_{40.1(6)} \mathrm{Co}_{39.8(8)} \mathrm{Ga}_{20.1(4)}$ & $\begin{array}{l}4.0889 \\
(7)\end{array}$ & $\begin{array}{c}5.407 \\
(1)\end{array}$ & $\begin{array}{l}8.448 \\
(2)\end{array}$ & $\begin{array}{c}186.8 \\
(1)\end{array}$ & 146 & 7.70 & 190 \\
\hline G1 & - & B & $\mathrm{Tb}_{39.9(8)} \mathrm{Co}_{40.7(4)} \mathrm{Ga}_{19.4(9)}$ & $\begin{array}{l}4.0882 \\
(7)\end{array}$ & $\begin{array}{l}5.405 \\
(1)\end{array}$ & $\begin{array}{l}8.451 \\
(2)\end{array}$ & $\begin{array}{c}186.7 \\
(1)\end{array}$ & 145 & & \\
\hline G2 & - & C & $\mathrm{Tb}_{39.9(3)} \mathrm{Co}_{39.4(2)} \mathrm{Ga}_{20.6(5)}$ & $\begin{array}{l}4.0952 \\
(5)\end{array}$ & $\begin{array}{l}5.4182 \\
(9)\end{array}$ & $\begin{array}{c}8.436 \\
(1)\end{array}$ & $\begin{array}{l}187.18 \\
(8)\end{array}$ & 101 & 9.83 & 98 \\
\hline G2 & - & $\mathrm{D}$ & $\mathrm{Tb}_{40.3(8)} \mathrm{Co}_{38.8(9)} \mathrm{Ga}_{21.0(2)}$ & $\begin{array}{l}4.0955 \\
(6)\end{array}$ & $\begin{array}{l}5.4196 \\
(9)\end{array}$ & $\begin{array}{l}8.435 \\
(1)\end{array}$ & $\begin{array}{l}187.22 \\
(9)\end{array}$ & 102 & & \\
\hline G3 & - & E & $\mathrm{Tb}_{39.7(8)} \mathrm{Co}_{38.6(7)} \mathrm{Ga}_{21.7(5)}$ & $\begin{array}{l}4.0969 \\
(5)\end{array}$ & $\begin{array}{l}5.4204 \\
(8)\end{array}$ & $\begin{array}{c}8.430 \\
(1)\end{array}$ & $\begin{array}{c}187.21 \\
(8)\end{array}$ & 92 & & \\
\hline G3 & - & $\mathrm{F}$ & $\mathrm{Tb}_{39.8(6)} \mathrm{Co}_{39.7(5)} \mathrm{Ga}_{21.5(4)}$ & $\begin{array}{l}4.0983 \\
(5)\end{array}$ & $\begin{array}{l}5.4230 \\
\quad(7)\end{array}$ & $\begin{array}{l}8.427 \\
(1)\end{array}$ & $\begin{array}{l}187.28 \\
(7)\end{array}$ & 90 & 10.6 & 45 \\
\hline G4 & SG4-1 & G & $\mathrm{Tb}_{39.6(7)} \mathrm{Co}_{37.7(9)} \mathrm{Ga}_{22.7(6)}$ & $\begin{array}{l}4.0976 \\
(7)\end{array}$ & $\begin{array}{l}5.418 \\
(1)\end{array}$ & $\begin{array}{l}8.423 \\
(2)\end{array}$ & $\begin{array}{c}187.0 \\
(1)\end{array}$ & 78 & 10.1 & 90 \\
\hline G4 & SG4-1 & $\mathrm{H}$ & $\mathrm{Tb}_{39.5(4)} \mathrm{Co}_{38.5(9)} \mathrm{Ga}_{22.1(8)}$ & $\begin{array}{l}4.0983 \\
(6)\end{array}$ & $\begin{array}{l}5.4189 \\
\quad(9)\end{array}$ & $\begin{array}{l}8.424 \\
(1)\end{array}$ & $\begin{array}{l}187.08 \\
(9)\end{array}$ & 75 & & \\
\hline G4 & SG4-2 & I & $\mathrm{Tb}_{39.4(5)} \mathrm{Co}_{37.7(6)} \mathrm{Ga}_{22.9(9)}$ & $\begin{array}{l}4.1026 \\
(5)\end{array}$ & $\begin{array}{l}5.4211 \\
(7)\end{array}$ & $\begin{array}{c}8.433 \\
(1)\end{array}$ & $\begin{array}{l}187.56 \\
(7)\end{array}$ & 76 & & \\
\hline G4 & SG4-3 & $\mathrm{J}$ & $\mathrm{Tb}_{39.1(1)} \mathrm{Co}_{38.4(6)} \mathrm{Ga}_{22.5(8)}$ & $\begin{array}{l}4.1046 \\
(7)\end{array}$ & $\begin{array}{l}5.425 \\
(1)\end{array}$ & $\begin{array}{l}8.437 \\
(2)\end{array}$ & $\begin{array}{c}187.9 \\
(1)\end{array}$ & 76 & & \\
\hline G4 & SG4-3 & K & $\mathrm{Tb}_{39.1(3)} \mathrm{Co}_{38.0(4)} \mathrm{Ga}_{22.9(2)}$ & $\begin{array}{l}4.1037 \\
(7)\end{array}$ & $\begin{array}{l}5.425 \\
(1)\end{array}$ & $\begin{array}{l}8.443 \\
(2)\end{array}$ & $\begin{array}{l}188.0 \\
(1)\end{array}$ & 71 & & \\
\hline
\end{tabular}




\subsection{Magnetic Properties}

Figure 6a-d show the $\chi_{\mathrm{ac}}(\mathrm{T})$ of all samples, categorized by the $T_{\mathrm{C}}$ of the $\mathrm{Tb}_{2} \mathrm{Co}_{2} \mathrm{Ga}$ phase, indicated by arrows. The ferromagnetic states of several samples were checked by magnetization curves, as mentioned below. As in other ferromagnetic compounds [12,13], the peak position of $\chi_{\text {ac }}(T)$ is employed as $T_{C}$, which would be systematically governed by the atomic composition (see also Table 3). In the inset of Figure $6 \mathrm{a}$, the $\chi_{\mathrm{ac}}(\mathrm{T})$ of the sample with the starting composition $\mathrm{Tb}_{42.9} \mathrm{Co}_{50} \mathrm{Ga}_{7.1}$ is exhibited. This sample contains the pseudo binary $\mathrm{TbCo}_{2-\mathrm{x}} \mathrm{Ga}_{\mathrm{x}}$ alloy and the $\mathrm{N}$ phase [6]. Two pronounced peaks are observed at approximately 250 and $60 \mathrm{~K}$, for which the pseudo binary $\mathrm{TbCo}_{2-x} \mathrm{Ga}_{x}$ alloy and the $\mathrm{N}$ phase are responsible, respectively [6]. The $x$ value of $\mathrm{TbCo}_{2-x} \mathrm{Ga}_{x}$ is estimated to be 0.22 , corresponding to that of $\mathrm{TbCo}_{2-\mathrm{x}} \mathrm{Ga}_{\mathrm{x}}$ exhibiting ferromagnetic transitions at approximately $260 \mathrm{~K}$ [12]. The $\chi_{\text {ac }}$ peaks of sample A at approximately $260 \mathrm{~K}$ and $55 \mathrm{~K}$ can also be ascribed to the parasitic phases of $\mathrm{TbCo}_{2-x} \mathrm{Ga}_{x}$ and the $\mathrm{N}$ phase, respectively. Another small hump at approximately $90 \mathrm{~K}$ is due to the impurity phase of $\mathrm{Tb}_{3} \mathrm{Co}_{3} \mathrm{Ga}$. These assignments are supported by the metallographic examination combined with the EDX measurement of sample A (see Tables 1 and 2). In sample $\mathrm{B}$, the $\chi_{\text {ac }}$ peak at $55 \mathrm{~K}$ evolves in accordance with the increased area of the $\mathrm{N}$ phase observed by the FE-SEM image. The $T_{C}$ intrinsic to the $\mathrm{Tb}_{2} \mathrm{Co}_{2}$ Ga phase is approximately $145 \mathrm{~K}$ for each sample. As shown in Figure $6 \mathrm{~b}$, sample $\mathrm{C}$ shows almost a single peak at $101 \mathrm{~K}$. The small amount of $\mathrm{N}$ phase detected by EDX is responsible for a small hump at $60 \mathrm{~K}$. The enlarged $\mathrm{N}$ phase in sample D leads to an obvious $\chi_{\text {ac }}$ peak at $60 \mathrm{~K}$, in addition to the ferromagnetic transition due to the $\mathrm{Tb}_{2} \mathrm{Co}_{2} \mathrm{Ga}$ phase at $102 \mathrm{~K}$. In samples $\mathrm{E}$ and $\mathrm{F}$ (see Figure $6 \mathrm{c}$ ), the $T_{\mathrm{C}}$ of the $\mathrm{Tb}_{2} \mathrm{Co}_{2} \mathrm{Ga}$ phase is further reduced to approximately $90 \mathrm{~K}$, and a small anomaly due to the $\mathrm{N}$ phase is observed in sample E. In sample $\mathrm{F}$, an $\chi_{\mathrm{ac}}$ anomaly due to the $\mathrm{N}$ phase might be masked by a large $\chi_{\mathrm{ac}}$ peak at $90 \mathrm{~K}$.
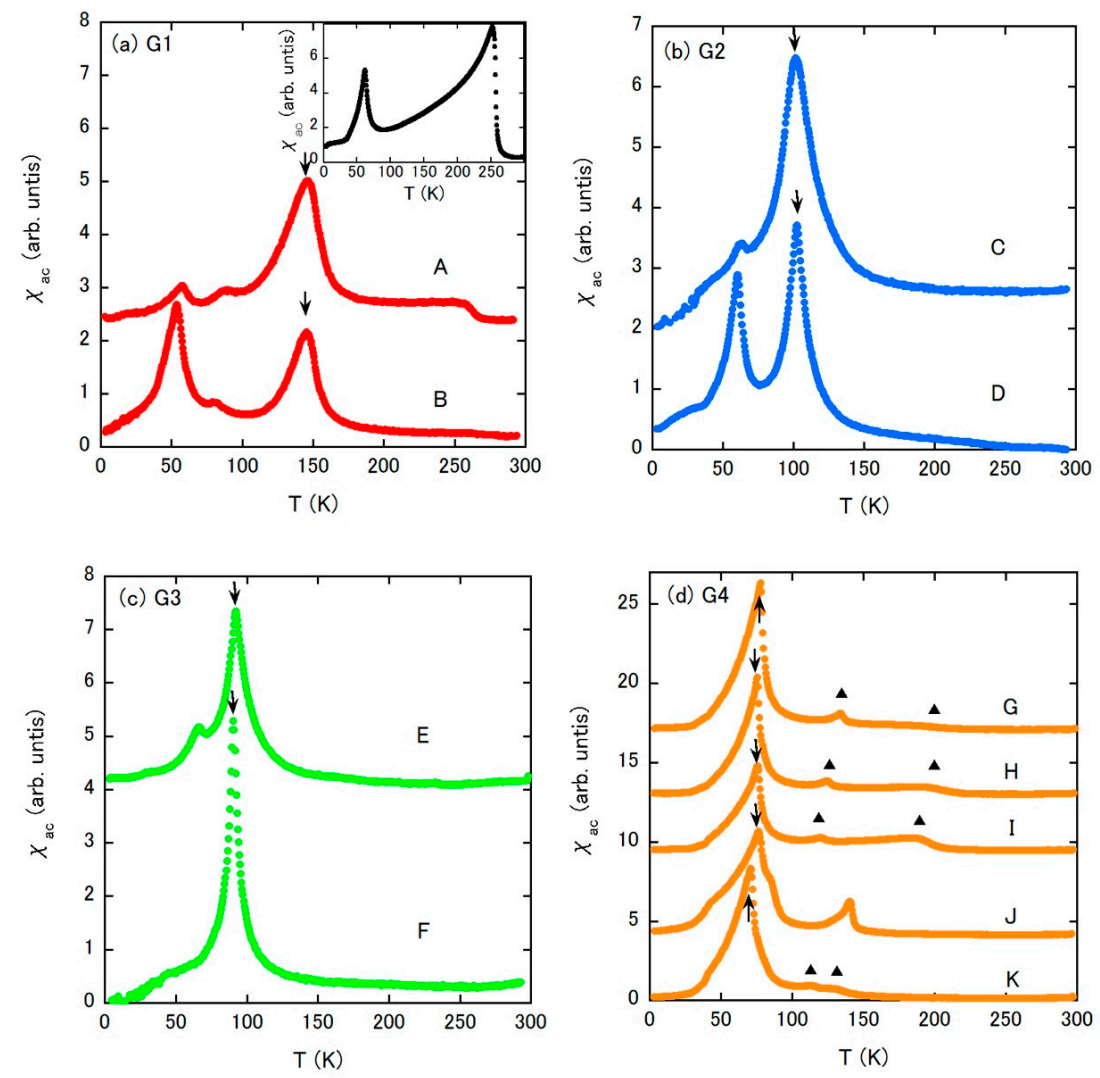

Figure 6. Temperature dependences of $\chi_{\mathrm{ac}}$ for samples (a) A and B, (b) C and D, (c) E and F, and (d) G to $\mathrm{K}$, respectively. The origin of each $\chi_{\mathrm{ac}}$ is shifted by a value for clarity. The inset of (a) is the $\chi_{\mathrm{ac}}(\mathrm{T})$ of the sample, with the starting composition of $\mathrm{Tb}_{42.9} \mathrm{Co}_{50} \mathrm{Ga}_{7.1}$. 
Figure $6 \mathrm{~d}$ shows the $\chi_{\mathrm{ac}}(\mathrm{T})$ of the G4 group. Except for sample J, two small anomalies due to impurity phases are observed, indicated by filled triangles in each sample. $\mathrm{Tb}_{1-\mathrm{x}} \mathrm{Co}_{\mathrm{x}} \mathrm{Ga}$ and $\mathrm{TbCo}_{2-x} \mathrm{Ga}_{\mathrm{x}}$ are responsible for the low and high temperature anomalies, respectively. The value of $x$ in $\mathrm{TbCO}_{2-x} \mathrm{Ga}_{x}$ is around 0.47 for each sample of $\mathrm{G}, \mathrm{H}$, and $\mathrm{I}$, and 0.7 for sample $\mathrm{K}$, respectively. The reduction trend of the magnetic transition temperature in $\mathrm{TbCo}_{2-x} \mathrm{Ga}_{x}$ with increasing $x$ is in agreement with the results in the literature [12]. In sample J, the peak at approximately $140 \mathrm{~K}$ would be induced by $\mathrm{TbCo}_{1-\mathrm{x}} \mathrm{Ga}_{\mathrm{x}}$, and the $\chi_{\mathrm{ac}}$ peak due to the $\mathrm{Tb}_{2} \mathrm{Co}_{2} \mathrm{Ga}$ phase is rather broad, reflecting the coexistence of two $\mathrm{Tb}_{2} \mathrm{Co}_{2} \mathrm{Ga}$ phases with slightly different atomic compositions. $\mathrm{Tb}_{1-\mathrm{x}} \mathrm{Co}_{\mathrm{x}} \mathrm{Ga}$ and $\mathrm{TbCo}_{1-\mathrm{x}} \mathrm{Ga}_{\mathrm{x}}$ may be related to $\mathrm{TbGa}$ with $T_{\mathrm{C}}=154 \mathrm{~K}$ [14], which probably supports the assignment of magnetic impurity phases in Figure $6 \mathrm{~d}$. We remark that the shapes of the $\chi_{\mathrm{ac}}$ peaks at $T_{\mathrm{C}}$ of the $\mathrm{Tb}_{2} \mathrm{Co}_{2} \mathrm{Ga}$ phases in the G4 group somewhat differ from those of the G1 to G3 groups. For the G4 group (Figure $6 \mathrm{~d}$ ), $\chi_{\mathrm{ac}}$ shows a $\lambda$-type anomaly, and the $\chi_{\mathrm{ac}}$ peaks of the G1 to G3 groups (Figure $6 \mathrm{a}-\mathrm{c}$ ) are more symmetric with respect to the temperature-axis.

Figure 7a shows $\chi_{\mathrm{dc}}(\mathrm{T})$ under the external field of 10 Oe of samples A, C, F, and G, respectively. In each sample, $\chi_{\mathrm{dc}}$ steeply increases below the approximate $T_{\mathrm{C}}$ of the $\mathrm{Tb}_{2} \mathrm{Co}_{2} \mathrm{Ga}$ phase. Figure $7 \mathrm{~b}$ shows the temperature dependences of the inverse $\chi_{\mathrm{dc}}$ of the four samples, which follow the Curie-Weiss law above $285 \mathrm{~K}, 275 \mathrm{~K}, 180 \mathrm{~K}$, and $255 \mathrm{~K}$, respectively (see the lines in Figure $7 \mathrm{~b}$ ). The effective magnetic moment $\mu_{\text {eff }}$ and the Weiss temperature $\Theta$ are summarized in Table 3. The value of $\mu_{\text {eff }}$ is near $9.72 \mu_{\mathrm{B}} / \mathrm{Tb}$, as expected for a free trivalent $\mathrm{Tb}$ ion, except in sample $\mathrm{A}$, in which the narrow temperature range for the Curie-Weiss fitting may disturb an accurate extraction of $\mu_{\text {eff. }}$. From the $\chi_{\mathrm{dc}}$ data, it is not clear whether the Co atom carries a magnetic moment or not.
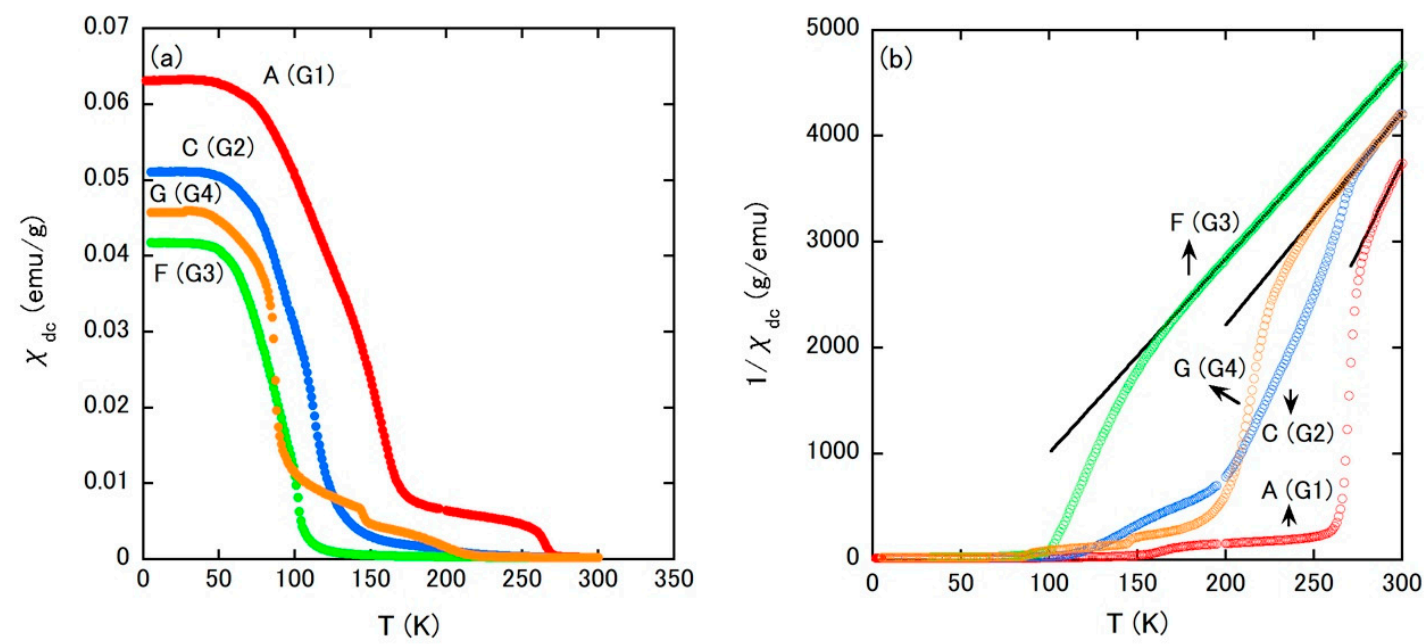

Figure 7. (a) Temperature dependences of $\chi_{\mathrm{dc}}$ for samples $\mathrm{A}, \mathrm{C}, \mathrm{F}$, and G. The external field is 10 Oe. (b) Temperature dependences of $1 / \chi_{\mathrm{dc}}$ for samples $\mathrm{A}, \mathrm{C}, \mathrm{F}$, and $\mathrm{G}$.

Figure 8a-d exhibit the $M-H$ (M: magnetization and $H$ : external field) curves measured at several temperatures denoted in the figures for samples $A, C, F$ and $G$, respectively. In samples A, C, and $\mathrm{F}$, below the $T_{\mathrm{C}}$ of the $\mathrm{Tb}_{2} \mathrm{Co}_{2} \mathrm{Ga}$ phases obvious hystereses grow, which are characteristic of ferromagnetism. For sample $\mathrm{G}$ in the $\mathrm{G} 4$ group, soft ferromagnetic behavior is observed down to $40 \mathrm{~K}$, which might suggest that the ferromagnetic nature differs from those of samples A (G1), C (G2), and $\mathrm{F}(\mathrm{G} 3)$. 

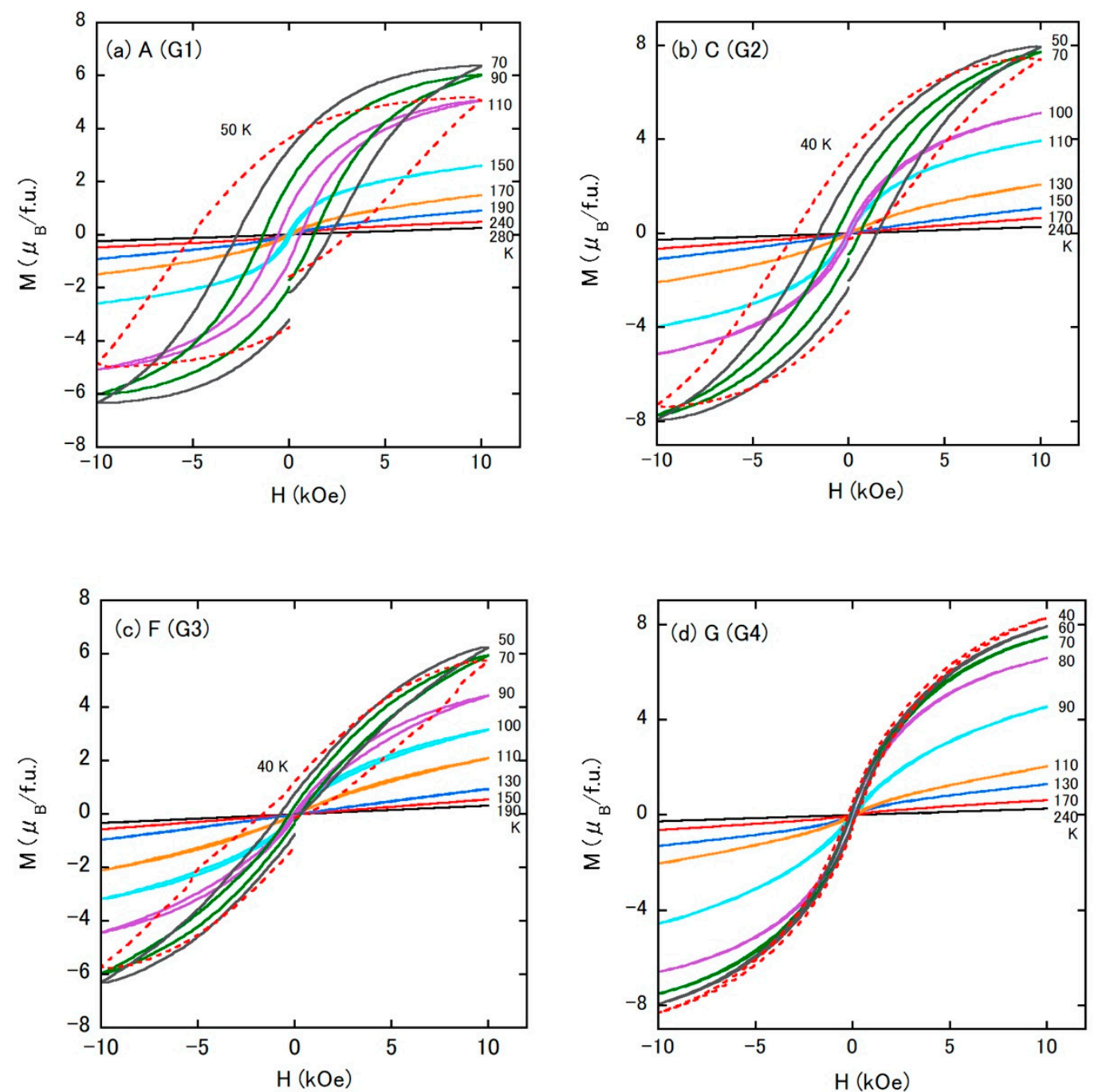

Figure 8. $M-H$ curves measured at several temperatures as denoted in the figures for samples (a) A, (b) C, (c) F, and (d) G, respectively.

\subsection{Relationship between the Ferromagnetic Properties and Crystal Structure Paremeters}

Hereafter, we discuss the relationship between the crystal structure parameters and $T_{\mathrm{C}}$. Figure $9 \mathrm{a}-\mathrm{C}$ are the 3D bar graphs of $T_{\mathrm{C}}$ as a function of $a$ and $b, a$ and $c$, and $b$ and $c$, respectively. In all figures, the G1 to G3 groups show systematic lattice parameter dependences of $T_{C}$; the increase of $a(b)$ and the decrease of $c$ reduce $T_{C}$. On the other hand, from the G3 to G4 group, the systematic dependence is not observed. All figures indicate that the samples in the G4 group can be divided into three subgroups of SG4-1, SG4-2, and SG4-3. Moreover, in the ternary phase diagram shown in Figure 2b, the starting atomic compositions of samples in the SG4-1 (SG4-3) subgroup are located in the region with a Tb concentration higher (lower) than that of sample I (SG4-2). As shown in Table 1, the order of the actual $\mathrm{Tb}$ compositions in the G4 group is consistent with that of the starting compositions, although the difference between the samples is smaller for the actual composition. Therefore, there might be some correlation between the lattice parameters and the $\mathrm{Tb}$ concentration for the $\mathrm{G} 4$ group. We note that the $T_{\mathrm{C}}$ of the sample in the $\mathrm{G} 4$ group seems to be slightly reduced with decreasing $\mathrm{Tb}$ concentration (see Table 3). 
(a)
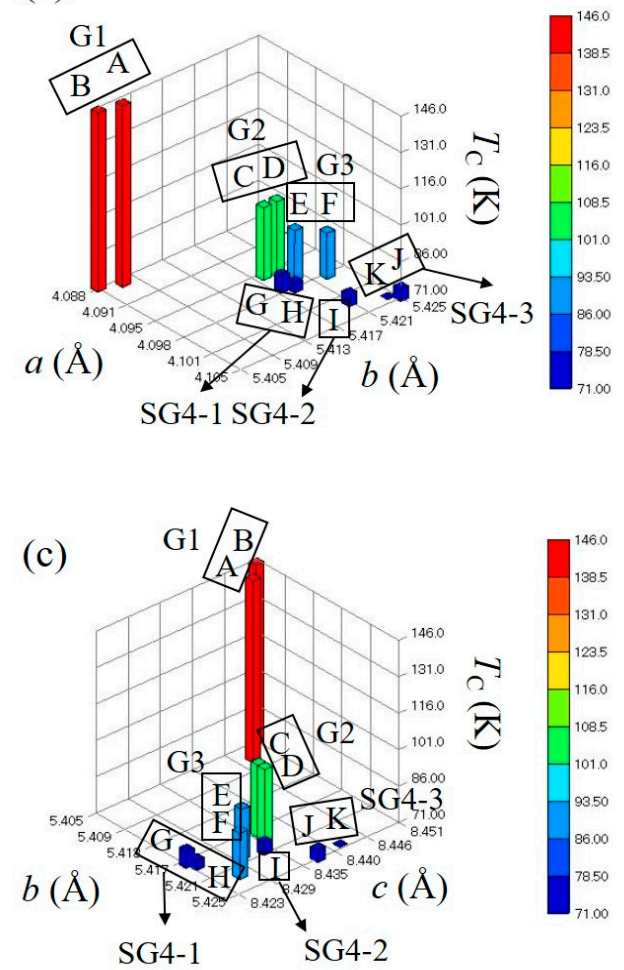

(b)

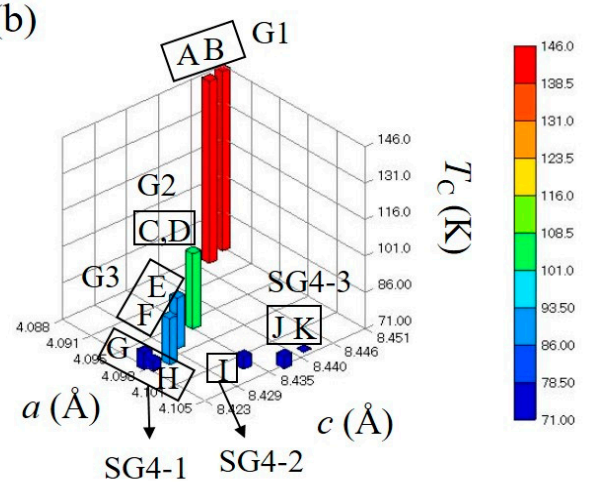

Figure 9. 3D bar graphs of $T_{\mathrm{C}}$ as a function of (a) $a$ and $b,(\mathbf{b}) a$ and $c$, and (c) $b$ and $c$, respectively.

Shown in Figure 10a,b are the 3D bar graphs of $T_{\mathrm{C}}$ as a function of $\mathrm{Tb}-\mathrm{Tb}$ and $\mathrm{Tb}-\mathrm{Co}$, and $\theta_{1}$ and $\theta_{2}$, respectively, especially focusing on the octahedron formed by the Tb and Co atoms (see also Figure 1). The $\mathrm{Tb}-\mathrm{Tb}(\mathrm{Tb}-\mathrm{Co})$ means the nearest $\mathrm{Tb}-\mathrm{Tb}(\mathrm{Tb}-\mathrm{Co})$ distance, and $\theta_{1}$ and $\theta_{2}$ are $\mathrm{Co}-\mathrm{Tb}-\mathrm{Co}$ angles in the octahedron. From the $\mathrm{G} 1$ to $\mathrm{G} 3$ groups, as the nearest $\mathrm{Tb}-\mathrm{Tb}(\mathrm{Tb}-\mathrm{Co})$ distance monotonously decreases (increases), $T_{\mathrm{C}}$ is reduced from $\sim 145 \mathrm{~K}$ to $\sim 90 \mathrm{~K}$. Then, both $\theta_{1}$ and $\theta_{2}$ become wider, and Figure 10a,b for the G1 to G3 groups suggest that the octahedron being compressed along the $c$-axis leads to the $T_{C}$ reduction. The expansion of $\mathrm{Tb}$-Co distance in particular means a weakened RKKY interaction through the weakened hybridization between the $\mathrm{Tb}$ and $\mathrm{Co}$ atoms. This might be responsible for the reduction of $T_{\mathrm{C}}$ down to $90 \mathrm{~K}$. At the present stage, the origin of further reductions of $T_{C}$ down to $\sim 75 \mathrm{~K}$ is unclear; however, a possible change of ferromagnetic properties in the G4 group can be conjectured as below. From the G3 to the G4 group, $\theta_{1}$ becomes narrower, while on the other hand, $\theta_{2}$ apparently continues to increase. The anisotropic behavior of the octahedral parameters is related to the difference of shapes of the $\chi_{\mathrm{ac}}$ peaks at $T_{\mathrm{C}}$ between the samples in the G1 to G3 groups and those in the G4 group, as mentioned above. 
(a)

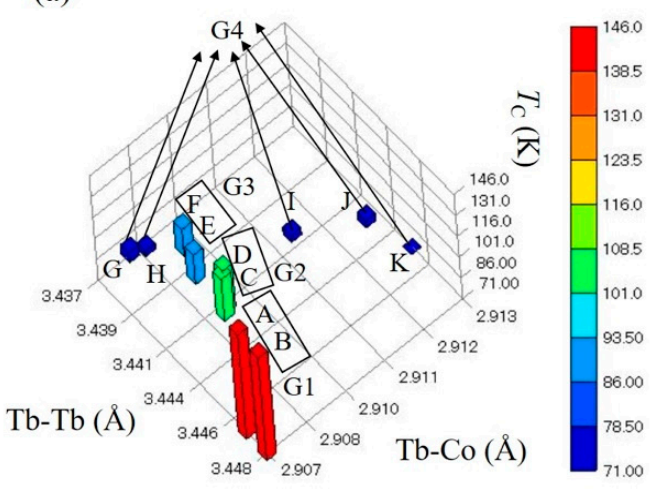

(b)

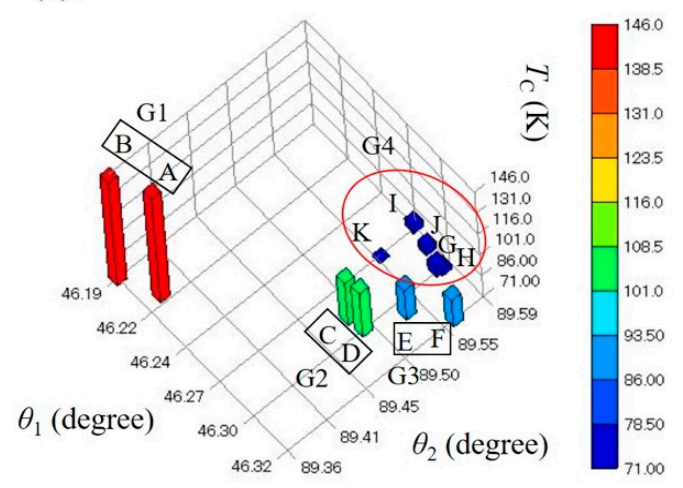

Figure 10. 3D bar graphs of $T_{\mathrm{C}}$ as a function of (a) $\mathrm{Tb}-\mathrm{Tb}$ and $\mathrm{Tb}-\mathrm{Co}$, and (b) $\theta_{1}$ and $\theta_{2}$, respectively. The errors of $\mathrm{Tb}-\mathrm{Tb}$ and $\mathrm{Tb}-\mathrm{Co}$ distances are $0.0005 \AA, 0.0003 \AA$, respectively. That of $\theta_{1}$ and $\theta_{2}$ is $0.007^{\circ}$.

\section{Conclusions}

The composition effect of the ferromagnetic properties in $\mathrm{Tb}_{2} \mathrm{Co}_{2} \mathrm{Ga}$, crystallizing into an orthorhombic $\mathrm{W}_{2} \mathrm{CoB}_{2}$-type structure, was investigated. The atomic composition obtained by the EDX measurement revealed the existence of a homogeneity range. The compound shows a remarkable composition effect of $T_{C}$ that is sensitive to the atomic composition, and ranges rather widely, i.e., from 75 to $145 \mathrm{~K}$. The composition dependence of $T_{C}$ is ascribed to the differences in the crystal structure parameters. For the samples in the $\mathrm{G} 1$ to $\mathrm{G} 3$ groups, the $\mathrm{Tb}-\mathrm{Tb}$ and $\mathrm{Tb}-\mathrm{Co}$ distances would be important factors in determining $T_{\mathrm{C}}$. The decrease of the $\mathrm{Tb}-\mathrm{Tb}$ distance leads to an increase of the $\mathrm{Tb}-\mathrm{Co}$ distance, which weakens the RKKY interaction through weakened hybridization between the $\mathrm{Tb}$ and $\mathrm{Co}$ atoms. The samples in the G4 group can be divided into three subgroups by the lattice parameter dependences of $T_{C}$, but the $\theta_{1}$ and $\theta_{2}$ angles in each sample show similar values. The anisotropic change of two angles below a $T_{\mathrm{C}}$ of $\sim 90 \mathrm{~K}$ makes the crystal feature of the octahedron different from that of the samples in the G1 to G3 groups. In reality, the anisotropic modification of the octahedron in the sample of the G4 group would be reflected in the $\lambda$-type $\chi_{\mathrm{ac}}$ anomaly at $T_{\mathrm{C}}$, which differs from those of the samples in the G1 to G3 groups.

Author Contributions: Conceptualization, J.K., N.S. and M.T.; methodology, J.K., N.S and M.T.; formal analysis, J.K. and M.T.; investigation, S.T., H.T. and N.S.; writing-original draft preparation, J.K.; writing-review and editing, J.K., N.S. and M.T.

Funding: This research received no external funding.

Acknowledgments: J.K. is grateful for the support provided by the Comprehensive Research Organization of Fukuoka Institute of Technology.

Conflicts of Interest: The authors declare no conflict of interest.

\section{References}

1. Rieger, W.; Nowotny, H.; Benesovsky, F. Die kristallstruktur von $\mathrm{W}_{2} \mathrm{CoB}_{2}$ und isotypen phasen. Mon. Chem. 1966, 97, 378-382. [CrossRef]

2. Sengupta, K.; Iyer, K.K.; Sampathkumaran, E.V. Large magnetoresistance and magnetocaloric effect above $70 \mathrm{~K}$ in $\mathrm{Gd}_{2} \mathrm{Co}_{2} \mathrm{Al}, \mathrm{Gd}_{2} \mathrm{Co}_{2} \mathrm{Ga}$, and $\mathrm{Gd}_{7} \mathrm{Rh}_{3}$. Phys. Rev. B 2005, 72, 054422. [CrossRef]

3. Fu, H.; Zou, M.; Guo, M.S.; Zheng, Q.; Zu, X.T. Structural, magnetic, and magnetothermal properties of $\mathrm{R}_{2} \mathrm{Co}_{2} \mathrm{Al}(\mathrm{R}=\mathrm{Tb}$, and Dy) compounds. Mater. Charact. 2011, 62, 451-455. [CrossRef]

4. Morozkin, A.V.; Genchel, V.K.; Garchev, A.V.; Yapaskurt, V.O.; Isnard, O.; Yao, J.; Nirmala, R.; Quezado, S.; Malik, S.K. Magnetic ordering of $\mathrm{Mo}_{2} \mathrm{NiB}_{2}$-type $(\mathrm{Gd}, \mathrm{Tb}, \mathrm{Dy})_{2} \mathrm{Co}_{2} \mathrm{Al}$ compounds by magnetization and neutron diffraction study. J. Magn. Magn. Mater. 2017, 442, 36-44. [CrossRef] 
5. Morozkin, A.V.; Garchev, A.V.; Yapaskurt, V.O.; Yao, J.; Nirmala, R.; Quezado, S.; Malik, S.K. Mo $\mathrm{MiB}_{2}$-type $\mathrm{Sm}_{2} \mathrm{Co}_{2} \mathrm{Al}$ and $\mathrm{Sm}_{2} \mathrm{Co}_{2} \mathrm{Ga}$ compounds: Magnetic properties and giant low-temperature coercivity. J. Solid State Chem. 2018, 260, 95-100. [CrossRef]

6. Kitagawa, J.; Terada, H.; Shirakawa, N.; Tsubota, M.; Nose, A.; Tanaka, S. Composition effect in ferromagnetic properties of $\mathrm{Tb}_{3} \mathrm{Co}_{3} \mathrm{Ga}$. Res. Phys. 2019, 15, 102591. [CrossRef]

7. Morozkin, A.V.; Yao, J.; Knotko, A.V.; Yapaskurt, V.O. Low-temperature coercivity of $\mathrm{Mo}_{2} \mathrm{NiB}_{2}$-type $\mathrm{Tb}_{2} \mathrm{Co}_{2} \mathrm{Ga}$ and $\mathrm{Tb}_{2} \mathrm{Co}_{2} \mathrm{Al}$-based solid solutions. J. Solid State Chem. 2019, 277, 406-414. [CrossRef]

8. Kitagawa, J.; Takeda, N.; Sakai, F.; Ishikawa, M. Effect of composition in (RE) ${ }_{3} \mathrm{Pd}_{20} \mathrm{Ge}_{6}(\mathrm{RE}=\mathrm{La}, \mathrm{Ce}$ and Nd). J. Phys. Soc. Jpn. 1999, 68, 3413-3416. [CrossRef]

9. Lu, Q.M.; Yue, M.; Zhang, H.G.; Wang, M.L.; Yu, F.; Huang, Q.Z.; Ryan, D.H.; Altounian, Z. Intrinsic magnetic properties of single-phase Mn1+xGa $(0<\mathrm{x}<1)$ alloys. Sci. Rep. 2015, 5, 17086. [PubMed]

10. Izumi, F.; Momma, K. Three-dimensional visualization in powder diffraction. Solid State Phenom. 2007, 130, 15-20. [CrossRef]

11. Tsubota, M.; Kitagawa, J. A necessary criterion for obtaining accurate lattice parameters by Rietveld method. Sci. Rep. 2017, 7, 15381. [CrossRef] [PubMed]

12. Dębiec, I.; Chełkowska, G. Magnetic, electric and XPS study of $\mathrm{Tb}\left(\mathrm{Co}_{1-\mathrm{x}} \mathrm{Ga}_{\mathrm{x}}\right)_{2}$ compounds. J. Magn. Magn. Mater. 2003, 261, 73-77. [CrossRef]

13. Miyahara, J.; Shirakawa, N.; Setoguchi, Y.; Tsubota, M.; Kuroiwa, K.; Kitagawa, J. Hill plot focusing on Ce compounds with high magnetic ordering temperatures and consequent study of $\mathrm{Ce}_{2} \mathrm{AuP}_{3}$. J. Supercond. Nov. Magn. 2018, 31, 3559-3564. [CrossRef]

14. Zheng, X.Q.; Chen, J.; Shen, J.; Zhang, H.; Xu, Z.Y.; Gao, W.W.; Wu, J.F.; Hu, F.X.; Sun, J.R.; Shen, B.G. Large refrigerant capacity of RGa (R=Tb and Dy) compounds. J. Appl. Phys. 2012, 111, 07A917. [CrossRef]

(C) 2019 by the authors. Licensee MDPI, Basel, Switzerland. This article is an open access article distributed under the terms and conditions of the Creative Commons Attribution (CC BY) license (http://creativecommons.org/licenses/by/4.0/). 